\section{Injections and Asian children}

Sir.

Dr Gatrad's observation' that many Asian mothers threaten their young children with a visit to the doctor for an injection is undoubtedly correct, but this practice is also to be noted in other communities. I have heard English and Scottish parents make the same threat. Those advising families on disciplining their children should discourage not only this particular practice but also the use of any threat that is false, because the parent is either not able or would be unwilling to carry it out, as the child soon learns that these threats are in many cases meaningless.

The 'take you to the doctor for an injection' threat is particularly pernicious as a seemingly innocent visit to the doctor may well result in a blood test being taken or an injection being given. For this reason parents should also never reassure their children that he is not going to give you an injection' or 'there will be no needles' unless they are absolutely confident that this will be so. I have experienced several unsatisfactory outpatient consultations when the investigation of the child could not properly be concluded because this promise had been falsely made as the child was coming through the clinic door.

Just as threats must always be true, so must promises.

\section{Reference}

1 Gatrad AR. Injections and Asian children. Arch Dis Child 1986;61:208.

W T HoulsBY University Department of Paediatrics and Child Health. The General Infirmary at Leeds, Leeds LS2 9NS. England

\section{Residual insulin secretion in insulin dependent diabetes mellitus}

Sir.

We read with interest the article by Rogers and Silink concerning the decline of residual $\beta$ cell function in diabetic children.' We feel that ascertainment bias may have led to an erroneous conclusion.

In 81 newly diagnosed diabetic children receiving conventional subcutaneous insulin, 24 hour urinary $C$ peptide is being measured at yearly intervals for a period of up to three years in a prospective longitudinal study in our laboratory. Using Rogers and Silink's cut off point, (().2 pmol C peptide/nmol creatinine/day) our results are presented in the accompanying Table. As can be seen. we agree that $C$ peptide excretion declines in all age groups with time. There is a clear age dependency of quantum of decline, however, at all times of follow up, with older children showing much more persistence of $\mathrm{C}$ peptide with time after onset of disease.

We can only assume that either the age spread of the author's study group was insufficient or that the younger
Table Age relation of $C$ peptide excretion* by diabetic children with years after onset of the clinical disease. $t$ Figures in parentheses are percentages

\begin{tabular}{|c|c|c|c|}
\hline \multirow{2}{*}{$\begin{array}{l}\text { Age at diagnosis } \\
\text { (years) }\end{array}$} & \multicolumn{3}{|c|}{ Years after diagnosis } \\
\hline & 1 & 2 & 3 \\
\hline $0-5$ & $\begin{array}{l}6 / 18 \\
(333)\end{array}$ & $\begin{array}{l}1 / 9 \\
(11)\end{array}$ & $\begin{array}{l}1 / 7 \\
(14)\end{array}$ \\
\hline$>5-10$ & $\begin{array}{l}16 / 29 \\
(55)\end{array}$ & $\begin{array}{l}12 / 27 \\
(44)\end{array}$ & $\begin{array}{l}4 / 21 \\
(19)\end{array}$ \\
\hline$>10-15$ & $\begin{array}{l}26 / 34 \\
(76)\end{array}$ & $\begin{array}{l}14 / 23 \\
(61)\end{array}$ & $\begin{array}{l}9 / 16 \\
(56)\end{array}$ \\
\hline
\end{tabular}

*24 hour urinary $($ peptide excretion $>01.2 \mathrm{pmol} / \mathrm{nmol}$ creatinine

$\Varangle$ Studied longitudinally: however. some children have not as yet completed the course.

ages were under represented. Their study was cioss sectional. The main reason for pointing out this error is that in several trials of immunosuppressive therapy in newly diagnosed diabetics using non-age matched controls similar erroneous conclusions have probably been drawn.

\section{Reference}

1 Rogers S. Silink M. Residual insulin secretion in insulin dependent diabetes mellitus. Arch Dis (hild 1985;60:20(1)-3.

$$
\begin{array}{r}
\text { R B Eli.tott, C PII.cher, and } \\
\text { S Francis } \\
\text { The University of Auckland Medical School, } \\
\text { Auckland, } \\
\text { New Zealand }
\end{array}
$$

Drs Rogers and Silink comment:

We would like to thank Dr Elliott and his colleagues for their comments and valuable longitudinal data. Although ours was a cross sectional study we feel that ascertainment bias would be negligible as the patients studied were both inpatients and outpatients representing over $80 \%$ of our diabetic clinic population. For ease of comparison we have presented our data in a similar format as Elliott et al. We expect Elliott et al's use of $0.2 \mathrm{pmol} C$ peptide/nmol creatinine/day instead of $(0.2 \mathrm{pmol} C$ peptide/ $\mu \mathrm{mol}$ creatinine/day is purely a typographical error. We do not consider either the age spread to be insufficient (age range ().2-19.3 years) nor the younger ages to be under represented.

Although we were unable to show as clear an age dependency as Elliott $e t$ al, there is a larger percentage of children with 24 hour urinary $C$ peptide excretion $>0.2$ $\mathrm{pmol} / \mathrm{umol}$ creatinine in those $>10$ years of age at diagnosis than those $<5$ years of age at diagnosis between one and two years' and after three years" duration of diabetes ('Table). At one to two years" and five to six years" duration of diabetes there was a significant difference $(p<0 \cdot 05)$ in the median 24 hour urinary $C$ peptide between the children $<5$ years at diagnosis and those $>10$ years at diagnosis but not at other times. Because of this unclear age dependency on $\mathrm{C}$ peptide excretion multiple regression analysis was carried out and the age at diagnosis was found 